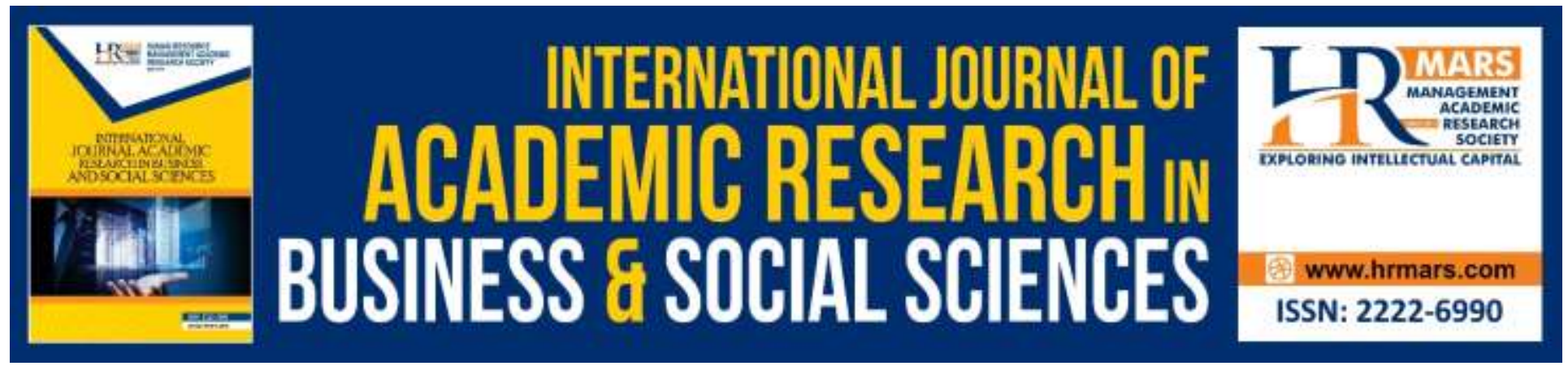

\title{
The Holy Quran Memorization in Globalization Era
}

\author{
Nursyahidah Mat Nafi, Wan Khairul Aiman Wan Mokhtar, Mohd Mustaffami \\ Imas
}

To Link this Article: http://dx.doi.org/10.6007/IJARBSS/v9-i11/6579

DOI: 10.6007/IJARBSS/v9-i11/6579

Received: 14 October 2019, Revised: 02 November 2019, Accepted: 15 November 2019

Published Online: 30 November 2019

In-Text Citation: (Ling et al, 2019)

To Cite this Article: Nafi, N. M., Mokhtar, W. K A. W., Imas, M. M. (2019). The Holy Quran Memorization in Globalization Era. International Journal of Academic Research in Business and Social Sciences, 9(11), 588-596.

Copyright: (c) 2019 The Author(s)

Published by Human Resource Management Academic Research Society (www.hrmars.com)

This article is published under the Creative Commons Attribution (CC BY 4.0) license. Anyone may reproduce, distribute, translate and create derivative works of this article (for both commercial and non-commercial purposes), subject to full attribution to the original publication and authors. The full terms of this license may be seen

at: http://creativecommons.org/licences/by/4.0/legalcode

Vol. 9, No. 11, 2019, Pg. 588 - 596

http://hrmars.com/index.php/pages/detail/IJARBSS

JOURNAL HOMEPAGE

Full Terms \& Conditions of access and use can be found at http://hrmars.com/index.php/pages/detail/publication-ethics 


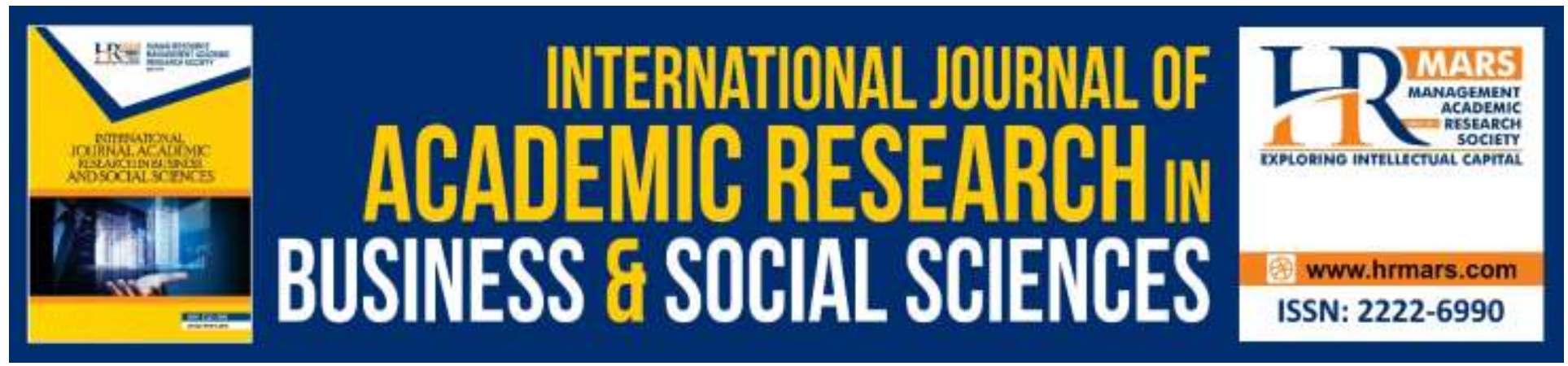

\title{
The Holy Quran Memorization in Globalization Era
}

\author{
Nursyahidah Mat Nafi, Wan Khairul Aiman Wan Mokhtar, Mohd \\ Mustaffami Imas \\ Universiti Sultan Zainal Abidin (UniSZA), Gong Badak Campus, 21300, Kuala Nerus, Terengganu, \\ Malaysia
}

\begin{abstract}
The purpose of this study was carried out to assess the memorization of the Quran in this era of globalization. The Quran is a way of life for people who want to be happy in the world and the hereafter. The Prophet Muhammad strongly encouraged his friends (Sahaba) and followers to memorize the holy verses of the Quran. People who memorize the Quran get a special position from Allah SWT and the Prophet Muhammad SAW. In addition, the Quran also promises goodness, blessing, and enjoyment for its memoirs. The questions that are often expressed in the present era of globalization are; what are the benefits and advantages of being the memoriser of the Holy Quran? What are the consequences of forgetting the memorization of the Holy Quran? What are the effective steps to memorize the Quran? This qualitative study uses a methodology in libraries that is a study does not involve field activities. This methodology it is most appropriate to carry out this study. In this study, researchers need to find relevant reference materials with the title of the study. Once the data is obtained, it is analysed by document analysis method.
\end{abstract}

Keywords: Memorization of the Holy Quran, Hafiz Quran, Document Analysis Method, Muslim Generation

\section{Introduction}

Nowadays there are so many extraordinary phenomena. The amount of entertainment that is inappropriate in watching, misleading associations, plus it's a sophisticated time, besides circulating comic books, novels, and social media. Making the Muslim generation start far away from the Quran. Causing the interest of the Muslim community to read the Quran is diminished and the worse is that some people make al-Quran as a display only. In contrast to the time of the Messenger of Allah, the companions were so glorifying and loving the Quran. No day without reading or memorizing al-Quran, no day without studying His interpretation and endeavoring to practice the Quran in everyday life. 
Now, it is still a lot of Quran memorizers who memorize only for pursuing targets but forget to learn and understand the interpretation of the Quran itself. So even if they memorize 30 Juz but some still have trouble understanding or even apply it in everyday life. Nowadays many al Quran gadget applications and their translation.

Some are supplemented with the laws of reading or 'tajwid', some are interpreted by the word, some are complete with foreign words. Yet the generation of Islam still rarely read al Quran. Although it is read-only to read without understanding its meaning.

\section{Research Methodology}

Research methodology is important for planning and organizing a research. To make a study in a proper way, research methodology must be applied. The application of research methodology produce a right findings (Mokhtar, 2017).

This study about "Memorization of the Holy Quran in Globalization Era" are using qualitative research. Focusing on exploratory and descriptive, searching by internet is used to get information. Using exploratory research is to identify a situation about Memorization of the Holy Quran in Globalization Era and find an alternative way for this situation. After that, the data was analysed by using content analysis method (Mokhtar, 2017; Razalli, Anal, Mamat, \& Hashim, 2018; Tsotsou \& Stamou, 2018).

\section{Findings and Research Discussion}

\section{Advantages of Being Huffaz Quran}

Memorizing Al Quran is an act in which a servant wants to get the pleasure of Allah SWT and accept the rewards in the world and in the hereafter. Hence, Allah SWT has promised a great reward for them all in the world and in the Hereafter. Among the advantages of a Quran reciter in the world are:

\section{They are Appointed as a Leader}

Someone who more memorizing is preferred to be a leader or a priest of prayer. It coincides with a hadith narrated by Abu Sa'id al Khudriy ra, He said,

Rasulullah SAW said, "If you are three (and you want to pray in a congregation) eat one of your most memorable ones to be a priest".

\section{They are Given a Heart and a Calm and Spacious Mind}

The person who memorizes the Quran is a person who is closer to Allah SWT. This is because the holy verses of the Quran are stored in their bosses and they seek to maintain them well. The Quranic memorizers will always "murojaah" or repeat their Quran recitation with the intention of keeping their memorization. Therefore, their hearts will always remember Allah SWT, and indeed the heart that always remembers Allah SWT will find peace as stated in Surah Al-Ra'd, verse 28 which reads:

$$
\text { الذين آمنوا وتطمئن قلوبهم بذكر الله ألا بذكر الله تطمئن القلوب }
$$


"The believers and their hearts are in harmony with the remembrance of Allah. Remember, just by remembering God's heart is resting".

\section{They are the Special People of Allah SWT}

From Anas r.a., Rasulullah S.A.W, He said: "Verily, Allah has a family of people."

Then Anas asked: "Who are they, O Messenger of Allah?"

He replied: "Who is the expert of the Quran (people who read or memorize the Quran and practice its contents). They are the family of God and the special person of God". (History of Majah).

\section{They can intercede for their Family Members}

The Messenger of Allah (peace and blessings of Allah be upon him) said: "Whoever reads the Quran and memorizes it, then Allah will bring it into heaven and grant him intercession for 10 members of his family, all of whom are all destined to enter hell." (Narrated by al-Tirmizi and alNasa'i).

\section{They will get the Highest Heaven}

From Aisha r.a, the Prophet S.A.W. said, "The number of levels of paradise is equal to the number of Quranic verses. Then the level of paradise entered by the Quranic memorizer is the highest level, there is no further level then. "(History of al-Baihaqi and al-Hakim)

There are many advantages for someone who memorizes the Quran that is not included here. They are truly human beings who have sacrificed many to fight for Islam. Therefore, our parents and our own should aim to be a Hafiz and educate their children well in order to succeed in the world and in the hereafter.

\section{Steps in Memorizing Al-Quran}

Here are tips on how to memorize the Quran 30 Juz easily and quickly for beginners.

\section{Straighten Intentions with Sincerity because of Allah}

The right intention is one of the conditions for memorizing the Quran. If the intention is wrong like there is riya (showing off), ujub (proud of yourself), or memorizing because you want to be called 'al-hafiz', then that is very fatal. With the right intention and sincere heart because God then feeling tired, lazy, and feeling difficult will not be a barrier in memorizing the Quran.

\section{Instilling Belief}

Instill in ourselves that memorizing the Quran is very easy, so we will feel easy. But if we instill the thought that memorizing the Quran is difficult, then it will be difficult. So, always selfmotivated to grow the belief that how to memorize the Koran that we do is easy. 


\section{Familiarize Yourself with the Quran}

Familiar with the Quran is one of the most effective and fast ways to memorize the Quran. Don't think of the complicated method of memorizing the Quran first. But think about how to start today we can read 5 Juz per day or today we have to memorize 1 verse per day.

\section{Improve Reading}

Before starting to memorize the Quran easily, we should improve reading. This is necessary so that we avoid misreading and make mistakes. Memorizing the Quran does have many virtues, but if there are still many ways to read the Quran wrong, it can make merit diminish.

\section{Using two Methods of Memorizing the Quran}

The method or how to memorize the Quran is a lot. But there are two main ways to memorize the Quran easily for beginners. The two ways to memorize the Quran are:

\section{Memorize Per Page}

We read one page that we will memorize three to ten times in tartil. When it's smooth, we memorize the page. After memorizing one page, we move to the next page. This method is more recommended using standard Medina manuscripts.

\section{Memorize Per Verse}

We read one verse that we will memorize three to ten times in tartil. When it's smooth, we memorize the verse. After memorizing the first verse we move to the next verse in the same way, and so on until one page. However, before moving to the next page, we should repeat the previous pages so that they are more memorized.

\section{Using One Type of Mushaf Quran}

Because the structure and appearance of the Quran pages sometimes vary by publisher, make sure to memorize the same Mushaf until the very least. The analogy of memorizing the Quran is actually similar to recording images into memory. So that the form of the Mushaf will affect our memorizing structure in the memory of the brain.

\section{Murojaah (Repeated Reading)}

The more often you repeat one verse, the easier the verse will be in your memory. So, do not let you feel that you have memorized several pages, we just memorize them without repeating them for a long time. This will cause a loss of memorization.

\section{Install the target of Memorizing the Quran}

Sometimes, in the middle of memorizing the Quran, we usually experience problems such as difficulty entering or memorizing the memorized ones, forgetting again. If so, our enthusiasm will usually decrease. So that we feel that the Quran is hard to memorize. So that we are not discouraged, we must set a target in memorizing the Quran. (Novalino, Heryanto, 2018) 


\section{Challenges in Memorizing Quran}

Whether we are ready or otherwise it is still present not invited. Rasulullah S.A.W. life journey who "ummiy", did not know what a book, what a pen, never taught a piece of Quranic verse suddenly ordered to receive the Quran in a memorable manner, would certainly be heavy to accept it. During self-building and the future of an al-Quran memorizer is forced to face all forms of testing. What matters is wisdom and how to handle all the forms of testing that come. An alQuran reciter is not just one of the two tests that come in, every single form of test that comes with can lead the Quran to the negatives. If it is mistaken for the consideration and the actions are taken normally one of the mistresses will be lost early before graduating tahfiz. One important thing to note here is that every student does not make all the tests and problems faced as obstacles to success.

A Quranic narrator should have the determination as they have ventured into tahfiz. The selection of this noble and challenging field should be tackled with a sincere attitude, commitment, determination and inner stimuli that comes from a pure heart. If not all efforts to memorize the Qur'an will be useless. Remember, $\mathrm{O}$ sons of Tahfiz, despite difficulties, the tiredness and fatigue of memorizing the Qur'an are sure there is the potential of waiting for us. A high glory, the glory that God has blessed and not all the people of this world will be able to obtain it, with the condition of overcoming all the tests and always feeling the sweetness of the honey of the Qur'an that is being sucked right now. The Arab proverb says;

$$
\text { تريدون ادراك المعالى رخيصةً \#\# فلا بدَّ دون الشّهد من أبِر النّحلِ }
$$

You want something expensive (glory) at a cheap price, while inevitably to get the honey must be dealing with a bee sting.

\section{Consequences of Forgetting The Memorizing Of Quran}

Allah Ta'ala says in the Quran, Sura Thaha:124,

$$
\text { وَمَنْ أَعْرَضَ عَنْ ذِكِرِي فَإنَّ لَهُ مَعِيشَةً ضَنْغًا وَنَحْشُرُهُ يَوْمَ الْقِيَامَةِ أَعْمَى }
$$

"And whoever turns away from My warning, then he will live a narrow life, and We will gather it on the Day of Resurrection in a blind state."

(QS Thaha: 124).

In fact, there are so many dangers that will befall people if they forget about or abandon the Quran's demands. Here are 10 dangers of forgetting the Quran that has been compiled by the Cordoba Quran team:

\section{Dhalalum Mubin, ضلال مبين}

The person who forgets the Qur'an will be in error as one who deviates and does damage warned against himself, eventually, he himself was broken and he was destroyed without being aware of it.

\section{ضhayyiqun haraj, ضيق حرج}

That is, the chest is narrow because it is away from Allah SWT, squeezed into a variety of problems and the chest is tired. Everyone has a problem, but God will expose the breasts of those 
who approach him with the Quran until he gets great patience and rigidity and eventually he is free of those problems.

\section{Ma'isyatun Dhonkun, معيشة ضنك}

That is a life that is hard and dark. Whereas the Qur'an is the source of light. means his life is bright, he must step in a divine way, while forgetting it he must have found darkness in his life.

\section{Umyul Bashirah, عمي البصيرة}

That is the blind eye of the heart. The blind man cannot distinguish between what is wrong and the wrong, the right and the wrong. Liver blindness results in one being unable to take lessons from the phenomenon he himself witnessed. Yet how much power God has revealed in this universe. In translating the Qur'an is explained:

"Were they not walking in the land, and they had a heart that they could understand or have ears that they could hear? For surely it is not the blind eye, but the blind, the heart that is in the breast."

\section{Qaswatul Qalb, قسوة القلوب}

(QS Al-Hajj: 46)

That heart is hard because of the eyes of the blind, the deeds born of the person are always bad, hard to remember, arrogant and underestimate the other person into the habit, arrogance will appear from his attitude and deeds.

\section{ظلم وذل, Zhulmun wadzull,}

That is dark and vile. Because his heart was blind and hard to the truth of the Quran. If a person is so deservingly humiliated, he is lost and humiliated.

"Indeed, he has misled me from the Reminder of the Quran when the Quran came to me. And Satan is a traitor to man."

(QS Al-Furqaan: 29)

\section{Shuhbatusy syaithan, صحبة الشيطان}

It's friends with Satan. A close-up to the creature he will follow the cursed. The Word of Allah SWT:

"Whoever turns away from the teachings of the Most Merciful God (Quran), we have devised for him the devil, so the devil is the one who is his best friend."

(QS Az-Zukhruf: 36)

Nis-Yan, النسيان

That's forgetting to itself, it's not self-remembered, because human memory is very limited, while it's far from the Quran. Be it alive. The Word of Allah SWT:

"Satan has dominated them and made them forget about God; they are the Shaitan. Know that the Shaitans are the losers."

Fasiq-Fusuq, الفسوق

(QS Al-Mujaadilah: 19) 
That person is the 'fasiq' when he has committed a great sin, when the devil has become a friend, commits a crime to be his habit, first to commit a minor sin, he long dares to commit a great sin, because he is accustomed to the act of sin. So, it becomes 'fasiq'.

\section{Nifaq, النفاق}

That is the pretense, just to cover his disgrace/disobedience. Because forgetting the Al-Quran people will be affected by this nifaq disease. In the Quran it is explained:

"When it is said to them: "Come to the law which Allah has sent down and to the messenger of the Messenger. "You will see the Hypocrites hinder (men) the strongest of you (approaching)."

\section{Conclusion}

(QS An Nisa': 61)

The Quran becomes a source of Islamic law which is very useful for use in life. The Quran is always maintained by Allah SWT without any addition and misappropriation, one way to maintain His holiness through memorization. It becomes 'fardu kifayah' to every Muslim and many advantages to read, memorize and understand the contents. The Prophet Muhammad was the first man to memorize the next Qur'an preserved by the companions, tabiien and now preserved by the Quran or known in this archipelago by the huffaz. Construction of Maahad Tahfiz in the world Islam now produces more of these groups including Malaysia. Its development is very encouraging whether the Maahad Tahfiz was built by government or private.

\section{Acknowledgement}

This paper is founded on the research project of the Fundamental Research Grant Scheme FRGS/1/2018/SSI03/UNISZA/02/2 (Project No: RR279). Special appreciation is owed to Ministry of Higher Education Malaysia (MOHE) and Universiti Sultan Zainal Abidin (UniSZA) for sponsoring and supporting this research.

\section{Corresponding Author}

Wan Khairul Aiman bin Wan Mokhtar (Ph.D), Senior Lecturer, Universiti Sultan Zainal Abidin (UniSZA), Gong Badak Campus, 21300 Kuala Nerus.

Email: wk_aiman@yahoo.com / wkhairulaiman@unisza.edu.my

\section{References}

Araby Academy. (2017). Quran Memorization: Its Importance \& Helpful Tips. Retrieved from https://www.arabyacademy.com/quran-memorization/.

Al-Munajjid, S. M. (2009). The advantages of the haafiz in this world and in the Hereafter. Retrieved from https://islamqa.info/en/answers/14035/the-advantages-of-the-haafiz-inthis-world-and-in-the-hereafter

Lewiston, B. (2011). The Structure, Format, Content, and Style of a Journal-Style Scientific Paper. Retrieved from 
INTERNATIONAL JOURNAL OF ACADEMIC RESEARCH IN BUSINESS AND SOCIAL SCIENCES

Vol. 9, No. 11, November, 2019, E-ISSN: 2222-6990 @ 2019 HRMARS

http://abacus.bates.edu/ ganderso/biology/resources/writing/HTW_Guide_Sections_37-2011.pdf.

Malik, M. (1997). Al-Qur'an, the Guidance for Mankind - English Translation of the Meanings of Al-Qur'an with Arabic. Retrieved from https://play.google.com/store/books/details?id=pLIXCQAAQBAJ.

Maryam, A. (2015). Trouble Memorizing the Quran? Activate Your Own Mode. Retrieved from https://aljumuah.com/trouble-memorizing-the-quran-activate-your-own-modemaryam-amirebrahimi/.

Mubashir, A. (2016). How Can I Memorise The Qur'an When I Keep Forgetting? - Stick to The Pillars. Retrieved from https://medium.com/how-to-memorise-the-quran/how-can-imemorise-the-quran-when-i-keep-forgetting-stick-to-the-pillars-5519cf7211ac.

Mokhtar, W. K. A. W. (2017). Concept Al-Hadīth Al-Mawḍ̄'iy as a Method of Collecting and Analyzing Research's Data. International Journal of Academic Research in Business and Social Sciences, 7(2), 2222-6990.

Nadim. (2009). 13 Steps to memorize the Quran by Yasir Qadhi. Retrieved from https://muslimmatters.org/2009/10/27/13-steps-to-memorize-the-quran-by-yasirqadhi/.

Nihal, K. (2012). How to Memorize The Qur'an And Not Forget It!. Retrieved from https://muslimmatters.org/2012/07/29/memorizing-quran-survival-of-the-fittest-notfor-the-weak/.

Novalino, Heryanto(2018). Effect of Competence and Work Loads on Motivation and Its Impact on the Performance of Budget Users in the Regional Working Unit of Padang City, International Journal of Academic Research in Accounting, Finance and Management Sciences 8 (4): 61-69.

Sheikhupuri, M. A. (2014). Guide Book for Huffaz: Quranic Memorisation Guide for Students. Retrieved from

https://play.google.com/store/books/details/Guide_Book_for_Huffaz_Quranic_Memori sation_Guide_f?id=f_fSAgAAQBAJ\&hl=en_US.

Theuns, K. (2007). Writing an academic journal article. Retrieved from http://btsau.edu.ua/sites/default/files/scopus/\%D0\%A1\%D1\%83\%D0\%BF\%D0\%B5\%D1 \%80\%20-\%20writing_an_academic_journal_article.pdf

Tsotsou, V. \& Stamou, A. (2018). Sociolinguistic representations of gender in children's cartoon movies in the past and the present: A comparative scene analysis of an older and of a contemporary Disney animation film. Multilingual Academic Journal of Education and Social Sciences, 6(1), 76-93 (in Greek).

Razalli, A. R., Anal, A., Mamat, N., \& Hashim, T. (2018). Effects of Bilingual Approach in Malay Language Teaching for Hearing Impaired Students. International Journal of Academic Research in Progressive Education and Development, 7(4), 109-121. 